\title{
1. INTRODUCTION AND OBJECTIVES, TECHNIQUES, AND EXPLANATORY NOTES ${ }^{1}$
}

\author{
Shipboard Scientific Party ${ }^{2}$
}

\section{INTRODUCTION AND OBJECTIVES}

Deep sea drilling has provided the materials necessary for the relatively new study of paleoceanography, which is concerned with the development of ocean systems through geologic time. Paleoceanography includes studies of the development of surface circulation, the history and effects of bottom-water circulation patterns, planktonic and benthic biogeographic development and rates of organic evolution, the history of biogenic productivity and its effects on sediment distribution, and the history of calcium carbonate and siliceous deposition and dissolution. All of these fields are interrelated. The early stages in evolving Cenozoic paleoceanography have seen the development of a general scenario in which the warm Mesozoic oceans have been replaced by cold oceans with bottom waters close to freezing, a pattern which has created strong environmental gradients between the tropics and the poles.

The global climatic changes did not proceed uniformly, but in a stepwise manner, punctuated by discrete and sudden coolings which seem to have resulted from marked changes in the geometry of the ocean basins and associated changes in ocean circulation. One of the most prominent changes took place near the Eocene/Oligocene boundary ( $38 \mathrm{Ma})$ when the cold, deep water of the oceans developed following the onset of ice formation around Antarctica. Subsequent coolings occurred during the middle Miocene (15 Ma) when much of the ice seems to have accumulated in the east Antarctic ice sheet, the latest Miocene when substantial west Antarctic ice sheets

\footnotetext{
${ }^{1}$ Kennett, J. P., von der Borch, C. C., et al., Init. Repts. DSDP, 90: Washington (U.S. Govt, Printing Office)

2 James P. Kennett (Co-Chief Scientist), Graduate School of Oceanography, University of Rhode Island, Narragansett, RI 02882; Christopher C. von der Borch (Co-Chief Scientist), School of Earth Sciences, Flinders University of South Australia, Bedford Park, South Aus tralia 5042; Paul A. Baker, Department of Geology, Duke University, Durham, NC 27708 . Charles E. Barton, Graduate School of Oceanography, University of Rhode Island, Narragansett, RI 02882 (present address: Bureau of Mineral Resourses, ganset, 378 . Stony Point, NY 10980; Jean-Pierre Caulet, Laboratoire de Géologie, Muséum National d'Histoire Naturelle, 43 Rue Buffon, 75005, Paris, France; Walter C. Dudley, Jr., Natural Sciences Division, College of Arts and Sciences, University of Hawaii at Hilo, Hilo, Hawail 96720; James V. Gardner, Pacific-Arctic Branch of Marine Geology, U.S. Geological Survey, 345 Middlefield Rd., Menlo Park, CA 94025; D. Graham Jenkins, Department of Earth Sciences, Open University, Walton Hall, Milton Keynes, MK7 6AA, Buckinghamshire, United King, Willi $\mathrm{H}$. Kingdom, WO 80160; Eriex 269, gang-Goethe Universität, Senckenberg-Anlage 32-34, D-6000 Frankfurt am Main, Federal Republic of Germany; Russell B. Merrill, Deep Sea Drilling Project A031, Scripps Institution of Oceanography, La Jolla, CA 92093 (present address: Ocean Drilling Project, Texas A\&M University, College Station, TX 77843-3469); Roger Morin, Department of Earth and Planetary Sciences, Massachusetts Institute of Technology, Cambridge, MA 02139 (present address: U.S. Geological Survey, Denver Federal Center, Denver, CO 80225); Campbell S. Nelson, De partment of Earth Sciences, University of Waikato, Private Bag, Hamilton, New Zealand; Christian Robert, Laboratoire de Géologie Marine, Centre Universitaire de Luminy, Case 901 , 13288 Marseille Cedex 09, France; M. S. Srinivasan, Department of Geology, Banaras Hindu University, Varanasi 221005 , India; Rüdiger Stein, Geologisch-Paläontologisches Institut, Universität Kiel, 2300 Kiel, Federal Republic of Germany (present address: Institute of Petroleum and Organic Geochemistry (ICH-5), Kernforschungslage Jülich GmbH, P.O. Box 1913, 5170 Jülich, Federal Republic of Germany); Akira Takeuchi, Department of Earth Sciences, Faculty of Science, Toyama University, Gohuku 3190, Toyama 930, Japan.
}

may have accumulated, and the late Pliocene (around $2.5 \mathrm{Ma}$ ) when Northern Hemisphere ice sheets began to develop, perhaps in response to the closing of the Central American Seaway (Isthmus of Panama). Present-day patterns have been established only recently and have often been significantly modified by the repeated climatic oscillations associated with glacial-interglacial episodes.

DSDP Leg 90 successfully obtained a traverse of highquality middle to upper Cenozoic cores between equatorial and northern subantarctic water masses in the southwest Pacific (Fig. 1, Table 1). This suite of cores was obtained using the hydraulic piston corer (HPC) and the extended core barrel (XCB) systems in order to provide higher core recovery and better-quality sections that are much less disturbed than standard rotary cores formerly obtained in this area by DSDP. The XCB, which was first successfully used during Leg 90 , is a core barrel that extends several centimeters beyond the main rotary drill bit, ensuring a less disturbed drilling environment ahead of the main water jets of the drill bit (see description under Techniques). It is used to core sediments after they have become too consolidated for use of the HPC. Most of the sites drilled during Leg 90 employed a combination of HPC and XCB, and core recovery was both high (average of about $90 \%$ ) and of good quality.

Leg 90 is one of several DSDP legs that were set up to complement each other for global paleoceanographic investigations. Others are Leg 68 (Caribbean, Gulf of Panama), Legs 72-76 (South Atlantic), Leg 85 (eastern equatorial Pacific) and Leg 87 (northwest Pacific). All were aimed at greater understanding of global paleoceanographic change and thus required continuous sequences exhibiting relatively high sedimentation rates. Sites were selected in areas exhibiting greater sediment thickness rather than the thin sediment cover characteristic of the early days of deep sea drilling, when basement rocks and overlying basal sediments were prime objectives. Furthermore, a pair of HPC holes was taken at each location to provide a better chance of complete recovery of the sediment section for high-resolution stratigraphic and paleoceanographic work.

Seven main sites and one minor site were cored during Leg 90 (Fig. 1, Table 1). A ninth site (Site 586) was drilled at the northern extremity of this same traverse during Leg 89 and is discussed in Leg 89 and Leg 90 Initial Reports. The nine sites are placed along a latitudinal transect to obtain paleoceanographic records for a number of distinct water masses and to maximize our ability to make correlations across the wide latitudes between equatorial and subpolar regions.

The physical oceanography of the modern southwest Pacific is still not well known. Knox (1970) has summarized the position of the several surface water mass 


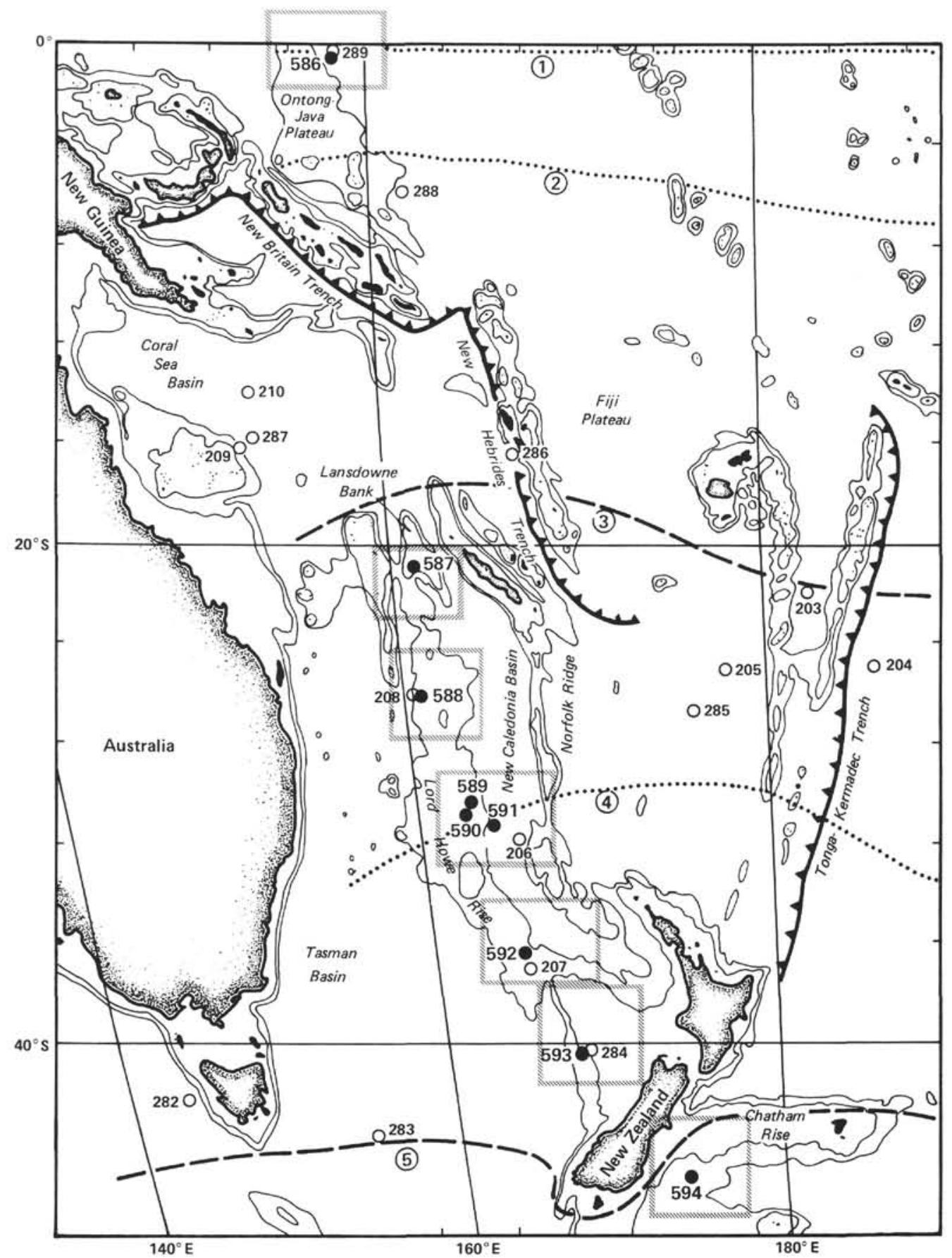

Figure 1. Physiographic diagram of the Leg 90 area showing 1000-fathom contour, adapted from Mammerickx, et al. (1971). Major water mass boundaries are illustrated as follows: 1, Equatorial Divergence; 2, Southern Tropical Divergence; 3, Southern Tropical Convergence; 4, Subtropical Divergence; 5, Subtropical Convergence; squares around sites represent areas of detailed bathymetry illustrated in individual site reports.

boundaries that occur in the region and separate the distinctive surface water masses shown in Figure 1. The sites were located so as to provide stratigraphic sections within each of the water masses, with Site 586 being in the tropical waters, Site 587 at the edge of the warm subtropics, Site 588 within the warm subtropics, Sites 589,590 , and 591 on the subtropical divergence in a transitional region located between warm subtropical and temperate areas, Sites 592 and 593 within temperate waters, and Site 594 in northern subantarctic waters immediately south of the subtropical convergence. All sites were located at water depths of between 1000 and $2200 \mathrm{~m}$ in areas that show simple pelagic sequences of calcareous sediments.

Previous rotary drilling in the region during DSDP Legs 21 and 29 demonstrated that the southwest Pacific is optimal for the study of relatively uncomplicated and continuously deposited carbonate sequences of Neogene 
Table 1. Leg 90 coring summary.

\begin{tabular}{|c|c|c|c|c|c|c|c|c|c|}
\hline Hole & $\begin{array}{c}\text { Dates } \\
(1982 / 83)\end{array}$ & Latitude & Longitude & $\begin{array}{l}\text { Water } \\
\text { Depth }^{\mathrm{a}}\end{array}$ & Penetration & $\begin{array}{c}\text { No. of } \\
\text { cores }\end{array}$ & $\begin{array}{c}\text { Meters } \\
\text { cored }\end{array}$ & $\begin{array}{l}\text { Meters } \\
\text { recovered }\end{array}$ & $\begin{array}{l}\text { Percentage } \\
\text { recovered }\end{array}$ \\
\hline 587 & Dec. 3-5 & $21^{\circ} 11.87^{\prime} \mathrm{S}$ & $161^{\circ} 19.99^{\prime} \mathrm{E}$ & $1101 \mathrm{~m}$ & 147.0 & 17 & 147.0 & 88.81 & 60.4 \\
\hline 588 & Dec. 6-7 & $26^{\circ} 06.7^{\prime}$ & $161^{\circ} 13.6^{\prime}$ & 1533 & 245.7 & 26 & 236.00 & 220.76 & 93.5 \\
\hline $588 \mathrm{~A}$ & Dec. 8 & $26^{\circ} 06.7^{\prime}$ & $161^{\circ} 13.6^{\prime}$ & 1533 & 344.4 & 18 & 108.40 & 84.27 & 77.7 \\
\hline $588 \mathrm{~B}$ & Dec. $8-10$ & $26^{\circ} 06.7^{\prime}$ & $161^{\circ} 13.6^{\prime}$ & 1533 & 277.4 & 31 & 277.4 & 255.87 & 92.2 \\
\hline $588 \mathrm{C}$ & Dec. $10-11$ & $26^{\circ} 06.7^{\prime}$ & $161^{\circ} 13.6^{\prime}$ & 1533 & 488.1 & 19 & 182.4 & 134.61 & 73.8 \\
\hline 589 & Dec. $12-13$ & $30^{\circ} 42.72^{\prime}$ & $163^{\circ} 38.39^{\prime}$ & 1391 & 36.1 & 4 & 36.1 & 35.08 & 97.2 \\
\hline 590 & Dec. 15 & $31^{\circ} 10.02^{\prime}$ & $163^{\circ} 21.51^{\prime}$ & 1299 & 26.2 & 3 & 26.2 & 26.36 & 100 \\
\hline $590 \mathrm{~A}$ & Dec. $15-17$ & $31^{\circ} 10.02^{\prime}$ & $163^{\circ} 21.51^{\prime}$ & 1299 & 280.8 & 27 & 254.6 & 224.17 & 88 \\
\hline $590 \mathrm{~B}$ & Dec. $17-19$ & $31^{\circ} 10.02^{\prime}$ & $163^{\circ} 21.51^{\prime}$ & 1299 & 499.1 & 53 & 499.1 & 465.26 & 93.2 \\
\hline 591 & Dec. $19-20$ & $31^{\circ} 35.06^{\prime}$ & $164^{\circ} 26.92^{\prime}$ & 2131 & 283.1 & 31 & 283.1 & 278.21 & 98.3 \\
\hline 591A & Dec. $20-22$ & $31^{\circ} 35.06^{\prime}$ & $164^{\circ} 26.92^{\prime}$ & 2131 & 284.6 & 30 & 284.60 & 233.15 & 81.9 \\
\hline $591 \mathrm{~B}$ & Dec. $23-24$ & $31^{\circ} 35.06^{\prime}$ & $164^{\circ} 26.92^{\prime}$ & 2131 & 500.4 & 24 & 229.80 & 130.86 & 56.9 \\
\hline 592 & Dec. $25-27$ & $36^{\circ} 28.40^{\prime}$ & $165^{\circ} 26.53^{\prime}$ & 1098 & 388.5 & 41 & 388.5 & 340.12 & 87.5 \\
\hline 593 & Dec. $28-30$ & $40^{\circ} 30.47^{\prime}$ & $167^{\circ} 40.47^{\prime}$ & 1068 & 571.5 & 60 & 571.50 & 468.21 & 81.9 \\
\hline $593 \mathrm{~A}$ & Dec. 30-Jan. 1 & $40^{\circ} 30.47^{\prime}$ & $167^{\circ} 40.47^{\prime}$ & 1068 & 496.8 & 27 & 257.30 & 227.71 & 88.5 \\
\hline 594 & Jan. 3 & $45^{\circ} 31.41^{\prime}$ & $174^{\circ} 56.88^{\prime}$ & 1204 & 505.1 & 53 & 505.1 & 299.72 & 59.3 \\
\hline 594A & Jan. 6-7 & $45^{\circ} 31.41^{\prime}$ & $174^{\circ} 56.88^{\prime}$ & 1204 & 639.5 & 26 & 249.6 & 161.55 & 64.7 \\
\hline 594B & Jan. 7-7 & $45^{\circ} 31.41^{\prime}$ & $174^{\circ} 56.88^{\prime}$ & 1204 & 42.9 & 5 & 42.9 & 34.18 & 79.6 \\
\hline
\end{tabular}

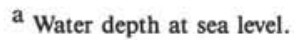

age between the equator and the subantarctic region. Unlike nearly all other oceanic regions, shallow-water platforms extend latitudinally over vast distances, providing an opportunity for drilling into oceanic pelagic sequences at shallow depths. These include Ontong-Java Plateau (Site 586) at the equator, Lord Howe Rise (Sites 587 through 592), the Challenger Plateau west of New Zealand (Site 593), and Chatham Rise east of New Zealand (Site 594).

The Lord Howe Rise is one of the major submarine topographic features of the southwest Pacific, extending northward from central western New Zealand to its northern limits at Lansdowne Bank at about $20^{\circ} \mathrm{S}$. The rise is about $2000 \mathrm{~km}$ long and $300 \mathrm{~km}$ wide and its crest generally lies at water depths ranging from 750 to $1200 \mathrm{~m}$ deep. This rise is bounded to the west by the Lord Howe and Tasman basins and to the east by New Caledonia Basin. According to Burns, Andrews, et al.(1973), Jongsma and Mutter (1978), and Wilcox et al. (1980), the crustal structure of the rise is continental in origin, with the eastern flank probably representing the ancient (preMaestrichtian) continental margin of the "AustralianAntarctic Supercontinent." The known geologic record began in the Late Cretaceous ( $96 \mathrm{Ma}$ ) with the eruption of rhyolites possibly at or near sea level (McDougall and van der Lingen, 1974). During the Maestrichtian, silty claystone (drilled at Site 207) was deposited in a shallow marine environment in the southern part of the rise. This was followed by subsidence to approximately present-day upper bathyal depths in the early Eocene. In the northern part of the rise, oceanic biogenic sedimentation had commenced by the late Cretaceous, when the rise reached upper bathyal depths.

The paleoceanographic importance of Lord Howe Rise is that it provides an extremely long north-south-trending shallow-water pedestal upon which lie pelagic sequences of Cenozoic age. Neogene sediments on the rise are carbonate oozes deposited above the foraminiferal lysocline, and hence, they contain calcareous assemblages of excellent preservational character. Since the rise is sur- rounded by basins in an oceanic setting, there is little terrigenous sedimentary dilution in the Cenozoic section. The previous drilling showed that the Neogene and late Paleogene sequence contains very few hiatuses. This can be compared with the Paleogene, which is much dissected by several hiatuses, including the major regional unconformity associated with the Eocene/Oligocene boundary (Kennett et al., 1972; Burns, Andrews, et al., 1973). The Neogene sequences that lie on the Lord Howe Rise are therefore ideal for paleoceanographic investigations over a wide latitudinal range.

During the Neogene the sites on the Lord Howe Rise have experienced about 5 to $10^{\circ}$ of northerly movement, in association with movement of the Indian Plate (J. Sclater and L. Meinke, pers. comm., 1983). This northward movement from higher to lower latitudes must have had an important effect upon the paleobiogeography of the planktonic microfossil assemblages.

In addition to the latitudinal traverse designed largely to study the history of surface-water paleoceanographic change and related sediment history, the Lord Howe Rise also offers a good opportunity to drill a traverse of sites at different water depths for paleoceanographic studies within the vertical water column. Three closely adjacent sites now provide such a traverse. These are Site 590 at $1299 \mathrm{~m}$, Site 591 at $2131 \mathrm{~m}$, and Site 206 at $3196 \mathrm{~m}$. These three sites, in combination, will provide the opportunity to carry out detailed studies of changes in the intermediate water masses between 1000 and 3000 $\mathrm{m}$ water depths.

Three previously drilled sites were reoccupied to provide much higher quality Cenozoic sequences (Sites 289, 208, and 284) and a new site close to Site 207 was also drilled.

Scientific investigations planned for Leg 90 materials include the following:

1. High-resolution Neogene biostratigraphy.

2. Latest Paleogene through Neogene paleoclimatic history and surface-water fluctuations in the region using stable isotopes and microfossils. 
3. Cross-latitudinal biostratigraphic correlations between sites.

4. Paleobiogeographic change of planktonic foraminifera and other microfossils in relation to paleoceanographic fluctuations and to the northward movement of the Lord Howe Rise during the Neogene.

5. Magnetostratigraphy of the cored sequences to enhance correlation and provide a geochronology.

6. Evolutionary studies of planktonic foraminifera to assist in evaluating different possible processes of evolution, such as punctuated equilibrium versus gradualism.

7. Benthic foraminiferal assemblage changes at these relatively shallow depths during the late Paleogene and Neogene to study paleobiogeography, taxonomic evolution, and the history of vertical water mass changes at intermediate depths in the southwest Pacific.

8. Stable isotopic studies of vertical water mass structure.

9. History of eolian sedimentation related to the development of Australian dry climates and deserts. Leg 21 scientists discovered a minor wind-blown quartz fraction in sediments younger than the middle Miocene of Site 208 and inferred that it was derived from Australia. Quantitative studies will be carried out and compared with paleoclimatic data.

10. Physical properties of sediments, including relations with seismic data.

11. Tephrochronology using volcanic ash layers.

\section{TECHNIQUES}

\section{Hydraulic Piston Corer (HPC) and Variable Length Hydraulic Piston Corer (VLHPC)}

In December of 1978, after a development period of approximately seven months, the Deep Sea Drilling Project deployed the first hydraulically actuated wire line piston corer (HPC). This coring system utilizes a hydraulic piston principle (Fig. 2). Fluid is pumped through the drill pipe, activating a piston-driven core barrel which, on failure of the shear pins, is ejected through the core bit into the sediment at the rate of approximately $20 \mathrm{ft}$./ s. This extremely high penetration rate is used to decouple the core barrel from the motion of the drill string. On completion of each coring operation, the core barrel assembly is retrieved by wire line as in a conventional coring operation. The core bit is then "washed" down to the next coring point, where the piston coring procedure is repeated.

The VLHPC is an improved coring system which came into operation in May 1981. The VLHPC is able to recover cores up to $9.5 \mathrm{~m}$ in length in a standard butyrate liner. The core bit used is a special 11.5-in. outside diameter (O.D.) roller cone bit with a 3.62-in. core throat. Coring is discontinued when the sediments become too indurated, a condition characterized by incomplete penetration of the core barrel. When this occurs, the newly developed extended core barrel (XCB) is utilized.

\section{Extended Core Barrel}

The XCB (Fig. 3) was developed in response to a long-recognized need to recover undisturbed cores in the intermediate zone where the sediment is too hard to be piston cored yet still too soft to be recovered effectively by means of standard rotary coring. It is designed to continue in the same hole after the VLHPC becomes ineffective. Rotating with the drill string, the XCB employs a cutting shoe studded with Stratapax (artificial diamond) cutting discs which extends 6 in. below the drill bit and which is lubricated by relatively low energy water jets. This allows the XCB to core soft sediments before they can be washed away by the more energetic drill bit jets. Harder sediments will cause the barrel to retract into the drill bit against the pressure of an internal spring, allowing indurated sediments to be cut predominantly by the roller cones and strong water jets of the drill bit.

The XCB uses the same bit as the VLHPC, allowing both tools to be run interchangeably in the same bottom-hole assembly. The bit has a 3.6 in. core throat to allow the core barrel to pass through, although a 2-5/ 16 in. diameter core is cut rather than the standard VLHPC 2-1/2 in. diameter core. The XCB also uses the same butyrate core liner as the standard and VLHPC coring systems; the liner and core catchers are set on bearings which decouple them from core barrel rotation.

\section{Physical Properties}

Laboratory equipment and measurement techniques utilized in the physical properties program are described in the following section. Not all of the properties listed below were measured for each core nor even in each hole. At sites with planned double HPC retrieval, many of the measurements were divided between the holes. The following physical properties were measured on the ship and are listed in the order in which they were made:

1. Saturated bulk density (with GRAPE)

2. Thermal conductivity (by needle probe method)

3. Acoustic velocity (with velocimeter)

4. Shear strength (with vane shear device)

5. Saturated bulk density, porosity, and grain density (by gravimetric techniques)

6. Carbonate content (by carbonate bomb technique).

\section{GRAPE Saturated Bulk Density}

Before the HPC cores were split, the $1.5 \mathrm{~m}$-long sections were passed through the Gamma Ray Attenuation Porosity Evaluator (GRAPE). The geologic material travels between a shielded gamma-ray source and a shielded scintillation detector. The beam attenuation is directly related to the material's saturated bulk density, defined as weight per unit volume, and is expressed in units of $\mathrm{g} / \mathrm{cm}^{3}$. The instrument was developed by Evans (1965) and produces a continuous analog record of downhole density variations. Its shipboard application by DSDP is presented by Boyce (1976).

The accuracy of the GRAPE density values depends strongly upon the degree to which the core material fills the liner, since voids or breaks in the sediment-rock sequence affect the theoretical gamma-ray path length. Bennett and Keller (1973) reported erratic results in their GRAPE density measurements. The HPC, however, provides good-quality cores which completely fill the liner, 


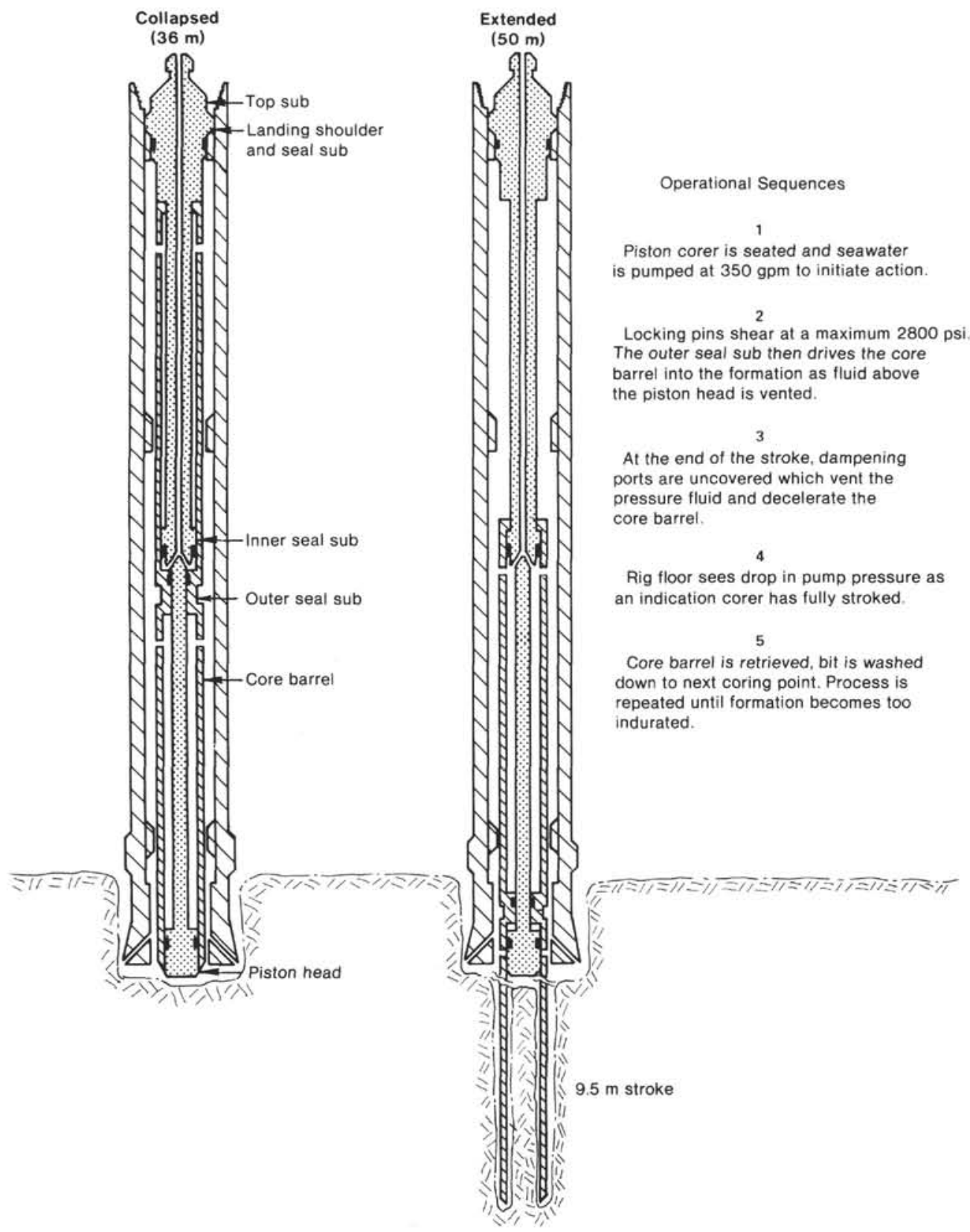

Figure 2. Hydraulic piston corer, illustrating prefiring (collapsed) and postfiring (extended) positions.

and Mayer (1982) found a very good correlation between the GRAPE-derived values and those determined in shore-based laboratories.

\section{Thermal Conductivity}

After the HPC cores had been exposed to the GRAPE device, sediment thermal conductivity was measured on the still unsplit cores. Holes (1/16 in. diameter) were drilled through the plastic liner and thermal conductivity probes were inserted through the liner and into the sediment. The Woods Hole Oceanographic Institution S-probe instrument and recorder were used in this particular case. Each probe contains a specified thermistor and a resistance wire which serves as a line heat source. Sediment temperature was measured with these needles, but further testing did not proceed until the cores reached thermal equilibrium within a maximum allowable drift. Thermal conductivity was subsequently determined by the needle probe method (Von Herzen and Maxwell, 1959), where the rise in temperature with time is logarithmically proportional to the conductivity. Temperature and pressure corrections necessary to estimate values at in situ conditions were applied (Morin and Silva, 1984). These were quite small, however, because of the generally shallow water depths.

\section{Sonic Velocity}

After the thermal conductivity had been measured, the cores were split and the speed of a compressional acoustic wave through the sediment was determined parallel to bedding. Measurements were made with the Hamilton Frame Velocimeter, utilizing $400 \mathrm{kHz}$ P-wave trans- 


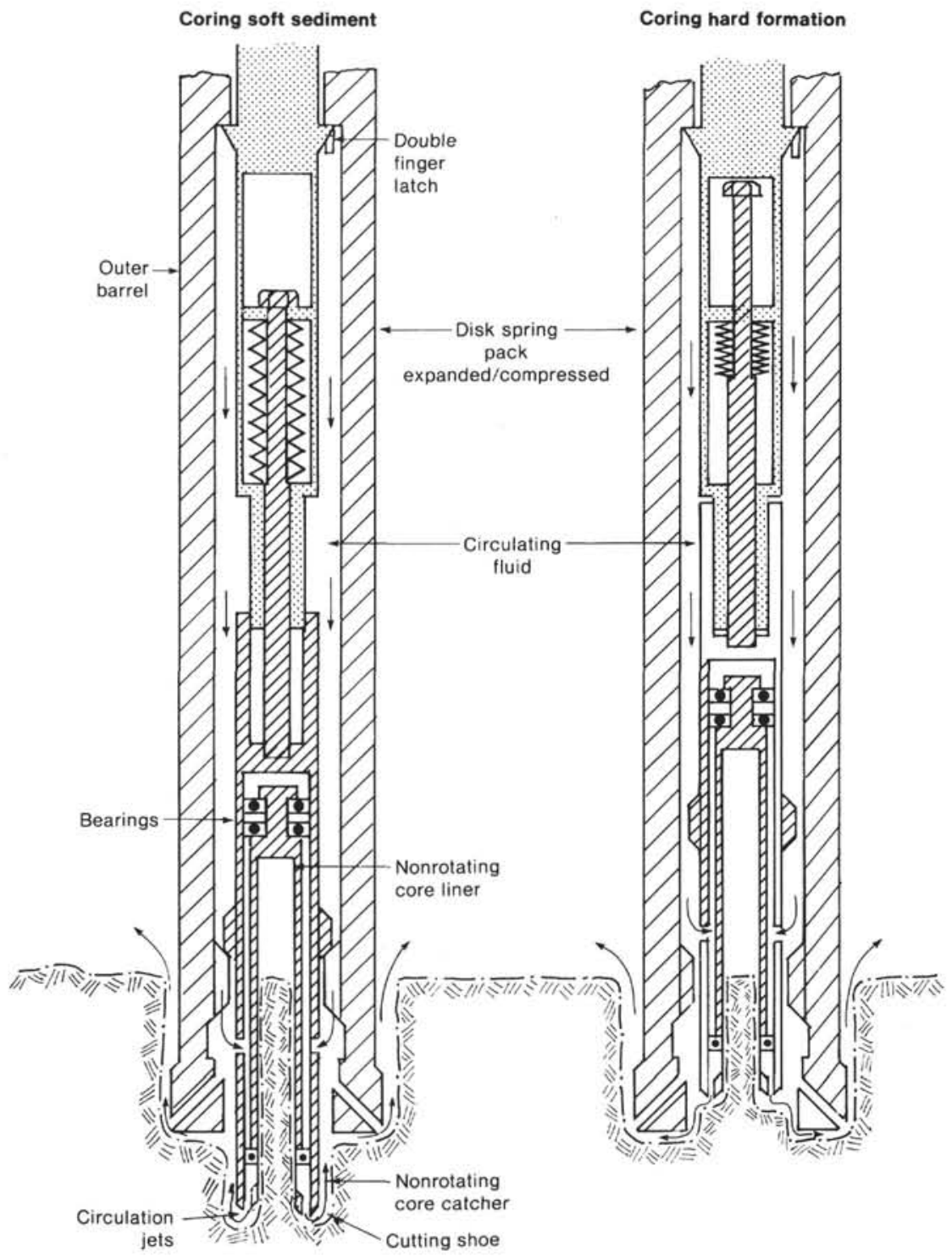

Figure 3. Extended core barrel, illustrating operation in both soft and hard formations.

ducers. One transducer was set directly on the sediment, the other was in contact with the core liner, and corrections for the liner material were applied to each measurement. Experimental theory and procedure are described by Boyce (1973). The technique is accurate to within $\pm 2 \%$.

\section{Shear Strength}

Immediately after the acoustic velocity was determined, the sediment shear strength was measured using a modified Wykeham Farrance miniature vane device. The vane was inserted into the sediment with its axis perpendicular to the core axis (parallel to bedding). Areas of obvious sediment disturbance were avoided when conducting this test. The vane rotates at a rate of $89^{\circ} / \mathrm{min}$. and the maximum torque at time of failure is recorded. This value is combined with the appropriate spring constant and vane size parameters in order to arrive at a sediment shear strength. The laboratory device and its theory of operation are described in detail by Boyce (1977).

\section{Gravimetric Techniques}

In most cases, gravimetric data were collected by filling metal cylinders of known weight and volume with soft sediment from the split cores and immediately weighing them on a Cent-O-Gram balance. The ring weights were subtracted from these latter weights and, with the volume known, values of wet-bulk density were determined. When the sediments proved to be too lithified to accept the rings, solid chunks were taken from the cores. These were weighed in and out of water in order to determine their volumes.

The samples were then dried for $24 \mathrm{hr}$. at $110^{\circ} \mathrm{C}$ and allowed to cool in a desiccator for approximately $2 \mathrm{hr}$. before being weighed again. The volume of pore space can thus be evaluated by dividing the difference between the wet and dry weights by the density of the pore fluid, seawater. Porosity, which is defined as the volume of voids divided by the total volume, can subsequently be determined. Grain density is defined as the weight of the solid constituent divided by the volume of the solids, and 
is expressed in $\mathrm{g} / \mathrm{cm}^{3}$. This property was calculated from the porosity and wet-bulk density values. Results proved to be very erratic, probably because the metal cylinders were not filled precisely to the calibrated volume. Most of the sediments retrieved consisted of very high percentages of $\mathrm{CaCO}_{3}$ and, in most cases, a sample grain density near that of $\mathrm{CaCO}_{3}$ could be used as a rough approximating value.

\section{Calcium Carbonate Content}

Calcium carbonate content was determined on the ship for selected samples by the carbonate bomb technique. A specimen is initially powdered and treated with $\mathrm{HCl}$ in a sealed container. The resulting $\mathrm{CO}_{2}$ gas and corresponding $\mathrm{CO}_{2}$ pressure are proportional to the $\mathrm{CaCO}_{3}$ content of the sediment sample. The method is described in detail by Müller and Gastner (1971).

\section{Paleomagnetism}

Intensities of magnetization of much of the sediment recovered were extremely low $(<0.05 \mu \mathrm{G})$ at every site and could only be measured using a cryogenic magnetometer. Directional scatter in the results was correspondingly high and the quality of the paleomagnetic record gradually deteriorated as a function of depth. It was possible to obtain a magnetic polarity stratigraphy back to approximately $3 \mathrm{Ma}$ at most sites (Fig. 4), but earlier than this only a few isolated polarity intervals could be identified.

Results described in the site reports that follow are based on NRM data only and are preliminary. Shipboard long-core measurements of the horizontal component of NRM were made on most cores from Hole 586B and Sites 587 and 588, but were abandoned when it became apparent that the sediments were too weakly magnetized to give reproducible results. As a rule most cores recovered with the HPC and XCB were subsampled at $50-$ and $75-\mathrm{cm}$ intervals respectively. Only the more strongly magnetized specimens at each site were measurable on the shipboard Digico magnetometer. Virtually all NRM measurements reported here were preformed on the three-axis cryogenic magnetometer at the University of Rhode Island, which had a background noise level of typically $0.004 \mu \mathrm{G}$. Specimens were measured in two different positions relative to the sample holder, thus eliminating the effect of the magnetic moment of the holder along the vertical and one horizontal axis. The effect of the moment of the holder along the third axis was not eliminated, but would not affect the sign of the inclination, which was used predominantly for determining polarities. Data were discarded if the angle between the magnetic vector determined for the two positions exceeded $45^{\circ}$. Likewise, for determining polarities, data with intensities less than $0.008 \mu \mathrm{G}$ were

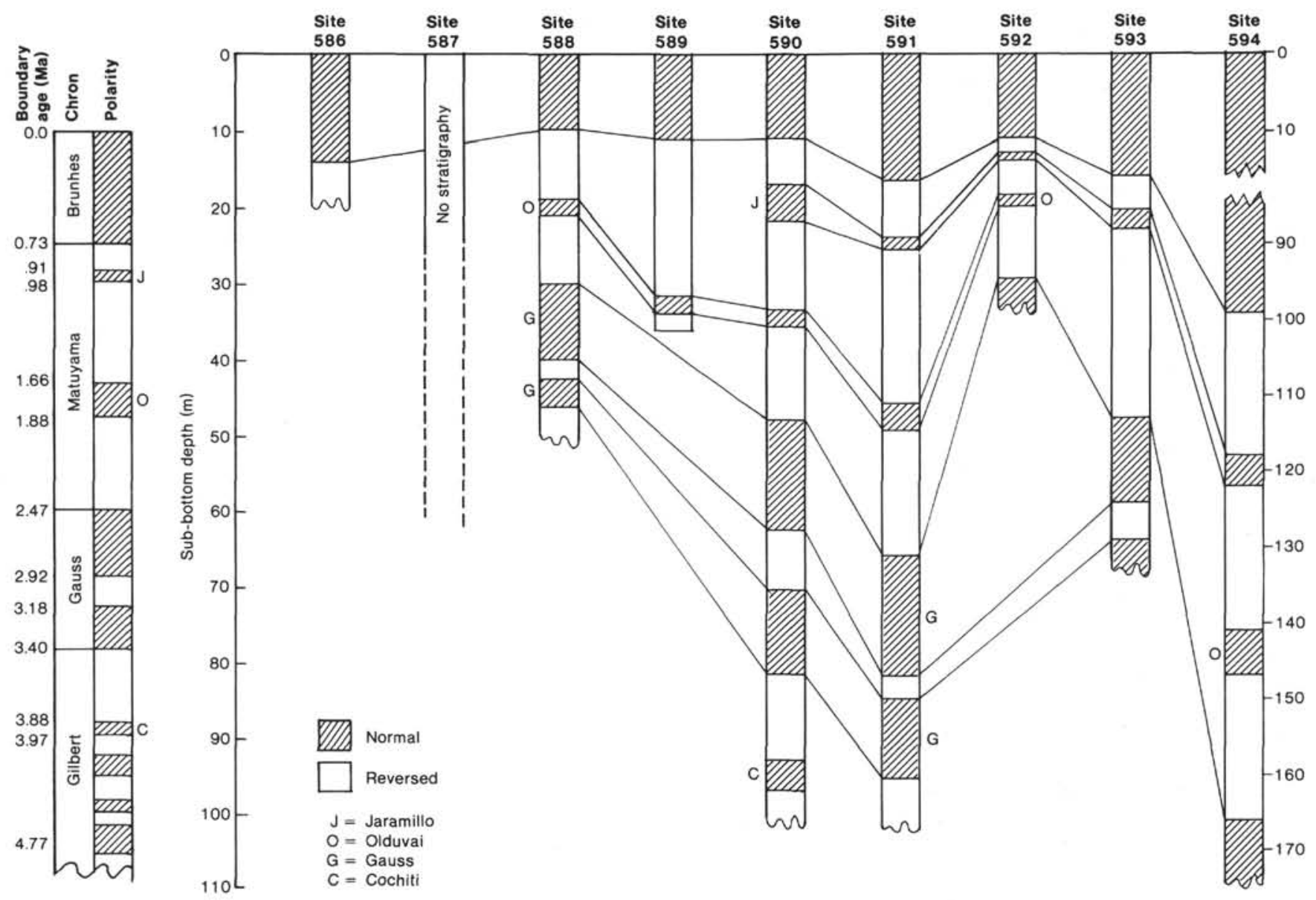

Figure 4. Magnetostratigraphy composite; column on left shows ages of epoch boundaries. 
discarded. Despite these very loose criteria, typically $10 \%$ of the data were rejected because of the extremely low intensities of magnetization (often less than $0.01 \mu \mathrm{G}$ ) which were characteristic of most of the sediments studied.

Although the Kuster orientation tool performed well on occasions, absolute orientation data were obtained for considerably fewer than $50 \%$ of the HPC cores recovered.

Low-field magnetic susceptibility measurements were made on a modified Digico bulk susceptibility bridge with a noise level of about $0.08 \mu \mathrm{G} / \mathrm{Oe}$. Much of the material measured was diamagnetic (negative susceptibility), but since magnetic susceptibility is a bulk property of the sediment it does not preclude a stable magnetic remanence which may be carried by only a small fraction of the magnetic grains.

A prominent high-intensity zone (about 1 to $10 \mu \mathrm{G}$ ) in the top few meters of nearly every section coincided with a pale brown, oxidized, surficial layer. Intensities dropped gradually to low values in the white-gray anoxic sediments beneath. As blebs and streaks of pyrite were common and in the latter, it is probable that a two-stage reduction of sulfates and iron oxides is occurring as described by Karlin and Levi (1983). The low intensities observed would be a consequence of this reduction process, together with dilution of the magnetic mineral input by very high carbonate contents (often 95 to almost $100 \%$ ).

At Sites 588, 592, and 593, a uniform region of enhanced intensity (about 0.5 to $1 \mu \mathrm{G}$ ) occurred within the latter part of the lower Miocene and the middle Miocene. The upper part of this region usually coincided with a pale yellow coloration of the sediments. Prominent high-intensity spikes (about 10 times neighboring values) were common in most sections, but did not correlate with any obvious macroscopic change in the sediments. These spikes could mark the remnants of altered ash layers. Measurements made on a number of the thin green-colored layers which were common did not indicate any of the intensity increase that would be expected in ash layers.

A comparison of shipboard NRM measurements with laboratory measurements made after storing specimens for six months showed a two- to threefold loss of intensity, most of which occurred during the first $36 \mathrm{hr}$. of storage. This was despite careful precautions to prevent the specimens drying out. Some loss of intensity during storage of wet sediments is common, though not usually so pronounced as noted here. It is difficult to believe that a small change in water content could produce such a large effect. Other possible causes are randomization of the alignment of small interstitial magnetic grains, and alteration of magnetic minerals which are unstable in the oxidizing storage environment.

Despite the high scatter in directions characteristic of these very weakly magnetized sediments, the NRM signal appears to be quite stable. Partial AF demagnetization tests were performed on a few of the more strongly magnetized specimens. Median destructive fields were typically in the range 125 to $300 \mathrm{Oe}(12.5$ to $30 \mathrm{mT})$. Directions generally remained stable up to fields of about
$400 \mathrm{Oe}(40 \mathrm{mT})$, beyond which most specimens were too weak to measure. Duplicate measurements indicated that the intensity threshold for obtaining repeatable polarities was about $0.008 \mu \mathrm{G}$. Scatter mean inclinations for most of the long sequences measured were in the range $-5^{\circ}$ to $-13^{\circ}$. This negative bias indicates the presence of a small normal-polarity overprint that is not sufficient to mask a primary reversal stratigraphy. A preponderance of intermediate and near-zero inclinations in a few zones suggests that long-term remagnetization can occur. However, this was not very common.

It was noticeable that the scatter in declinations was much greater than for the corresponding inclinations. Although the cause of this is unclear it suggests that cores become severely twisted within the core liners during coring, handling, and slicing. For this reason polarity interpretations have been based almost entirely on inclination data.

\section{EXPLANATORY NOTES}

\section{Numbering of Sites, Holes, Cores, Samples}

Drill site numbers run consecutively from the first site drilled by Glomar Challenger in 1968; thus each site number is unique. A site refers to the hole, or holes, drilled while using one acoustic positioning beacon. Several holes may be drilled at a single locality by pulling the drill string above the seafloor ("mud line") and offsetting the ship some distance (usually $100 \mathrm{~m}$ or more) from the previous hole. This sometimes becomes necessary where there is insufficient soft sediment at the last location to "spud in" or bury the bottom-hole assembly.

The first (or only) hole drilled at a site takes the site number. Additional holes at the same site are further distinguished by a letter suffix. The first hole has only the site number; the second has the site number with suffix " $A$ "; the third has the site number with suffix " $\mathrm{B}$ "; and so forth. It is important for sampling purposes to distinguish the holes drilled at a site, since recovered sediments or rocks usually do not come from equivalent positions in the stratigraphic column at different holes.

Cores are numbered sequentially from the top down. In the ideal case, they consist of $9 \mathrm{~m}$ of sediment or rock in a cylindrical plastic liner. In addition, a short sample is obtained from the core catcher (a multifingered device at the bottom of the core barrel which prevents cored materials from sliding out during core-barrel recovery). This usually amounts to about $20 \mathrm{~cm}$ of sediment and is stored separately. This sample, from each core, represents the lowest stratum recovered in the particular cored interval. The core-catcher sample is designated by CC (e.g., 590A-6, CC is the core-catcher sample of the sixth core taken in the second hole drilled at Site 590).

The cored interval is the interval in meters below the seafloor measured from the point at which coring for a particular core was started to the point at which it was terminated. This interval is generally $9.5 \mathrm{~m}$ (nominal length of a core barrel) but may be shorter if conditions dictate. Cores and cored intervals need not be contiguous. In soft sediment, the drill string can be "washed 
ahead" without recovering core by applying sufficiently high pump pressure to wash sediment out of the way of the bit. In a similar manner, a center bit, which fills the opening in the bit face, can replace the core barrel if drilling ahead without coring is necessary.

When a core is brought aboard Glomar Challenger, it is labeled and the plastic liner and core cut into $1.5-\mathrm{m}$ sections. A full 9-m core would thus consist of six sections, numbered from the top down as 1 to 6 . (The discrepancy between the $9.0-\mathrm{m}$ core and $9.5-\mathrm{m}$ core is discussed below.) Generally, somewhat less than $9 \mathrm{~m}$ is recovered. In this case, the sections are still numbered starting with 1 at the top, but the number of sections is the number of $1.5-\mathrm{m}$ intervals needed to accommodate the length of core recovered; this is illustrated in Figure 5 .

Thus, as shown, recovery of $3.6 \mathrm{~m}$ of sediment would result in a core with three sections, with a void of $0.9 \mathrm{~m}$ at the top of the first section. By convention, and for convenience in routine data handling at the Deep Sea Drilling Project, if a core contains a length of material less than the length of the cored interval, the sections of that recovered material are arbitrarily placed at the top of the cored interval, with the top of Section 1 (not always the top of the sediment) located at the top of the cored interval.

It was noted above that a discrepancy exists between the usual coring interval of $9.5 \mathrm{~m}$ and 9-m length of core recovered. The core liners used are actually $9.28 \mathrm{~m}$ in length, and the core catcher accounts for another $0.2 \mathrm{~m}$. In cases where the core liner is recovered full to the top, the core is still cut into $1.5-\mathrm{m}$ sections, measured from the top of the liner.

Samples taken from core sections are designated by the interval in centimeters from the top of the core section from which the sample was extracted; the sample size in $\mathrm{cc}\left(\mathrm{cm}^{3}\right)$, is also given. Thus, a full sample designation would consist of the following information:

Leg

Site (hole , if other than first hole)

Core number

Section number

Interval in centimeters from top of section

Volume.

Sample 590A-1-3, 122-124 cm (10 cc) designates a $10-\mathrm{cm}^{3}$ sample taken from Section 3 of Core 1 from the second hole drilled at Site 590. The depth below the seafloor for this sample would then be the depth to the top of the cored interval plus $3 \mathrm{~m}$ for Sections 1 and 2, plus $122 \mathrm{~cm}$, which represents the depth below the top of Section 3 .

\section{Lithologic Classification}

The basic lithological classification used to name a sediment type in this volume is a modified version of the system devised by the JOIDES Panel on Sedimentary Petrology and Physical Properties. We modified the basic classification to describe only the facies we recovered. The classification is descriptive, no genetic implication is intended, and the divisions between sediment types are often artificial. The assignment of a name was based on properties that were estimated aboard ship.

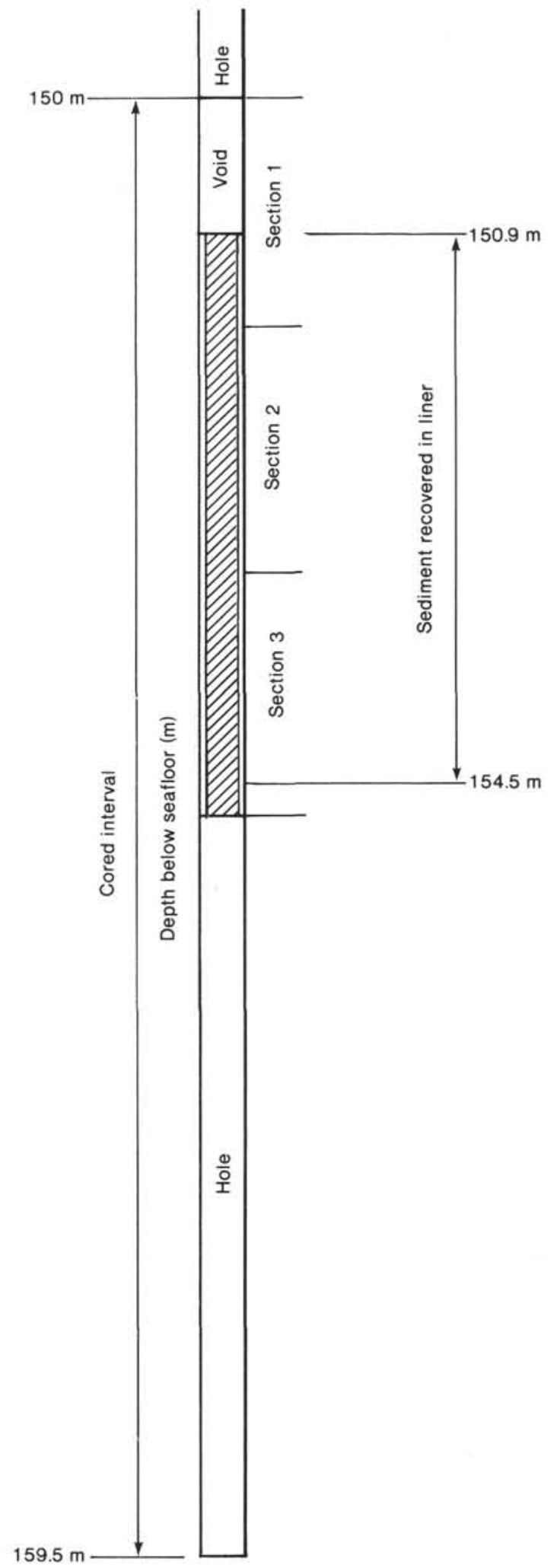

Figure 5. Position of incomplete sediment recovery within the cored interval.

Names of sediments are defined only on the basis of a qualitative estimate of composition and texture from a microscopic examination of smear slides. Colors were matched with the Geological Society of America Rock- 
Color Chart, and the full color code is recorded on the core forms at the end of each site chapter.

Four classes were used for firmness. Soft is used to denote an ooze with little strength that is readily deformed by spatula or finger. The term firm is used to describe sediment that is stiff and resists deformation by spatula or finger. The terms chalk and limestone denote calcareous sediments with the consistency of blackboard chalk or harder. The sediment classification used on Leg 90 is outlined below.

\section{Classification and Nomenclature Rules}

\section{Rules for Class Limits and Sequential Listing of Constituents in a Sediment Name}

A. Major Constituents: Sediment assumes names of those constituents present in major amounts (major is defined as greater than $25 \%$ ). Where more than one major constituent is present, the one in greatest abundance is listed farthest to the right. The remaining major constituents are listed progressively farther to the left in order of decreasing abundance. (See second example in Rule 1B.)

B. Minor Constituents: Constituents present in the amounts of $5-25 \%$ are prefixed to the sediment name by the term bearing.

The following example illustrates sediment names for various percentages of foraminifers and nannofossils in a two-component sediment.

\begin{tabular}{ccl}
\hline Foraminifers & Nannofossils & \multicolumn{1}{c}{ Description } \\
\hline $0-5$ & $95-100$ & Nannofossil ooze \\
$5-25$ & $75-95$ & Foraminifer-bearing nannofossil ooze \\
$75-95$ & $5-25$ & Nannofossil-bearing foraminifer ooze \\
$95-100$ & $0-5$ & Foraminifer ooze \\
\hline
\end{tabular}

A three-component sediment with a composition of $50 \%$ nannofossils, $30 \%$ foraminifers, and $20 \%$ diatoms would be called a diatom-bearing foraminifer nannofossil ooze. An example of one containing terrigenous components, say $10 \%$ silt, $30 \%$ clay, and $60 \%$ nannofossils is a siltbearing clayey nannofossil ooze.

\section{Specific Rules for Calcareous and Siliceous Tests}

A. Nannofossil is applied only to the calcareous tests of coccolithophorids, discoasters, and the like.

B. The terms calcareous and siliceous, depending on skeletal composition, are applied where no attempt was made to distinguish fossils as to major subgroup. Thus if no estimate is made, a mixture of radiolarians, diatoms, and silicoflagellates would be called a siliceous ooze. Where the distinction is made, the appropriate fossil name is used.

C. Fossil tests are not qualified by a textural term unless they have obviously been redeposited.

\section{Determinations of Shipboard Mineralogy and Lithology}

\section{Smear Slides}

Smear slides were the principal means of identifying sediment components on the ship. Component abun- dances in smear slides are based on a semiquantitative visual estimate, using the following classes:

$$
\begin{aligned}
<1 \% & \text { Trace (T) } \\
1-5 \% & \text { Rare (R) } \\
5-25 \% & \text { Common (C) } \\
25-75 \% & \text { Abundant (A) } \\
>75 \% & \text { Dominant (D) }
\end{aligned}
$$

Many cores contain important minor lithologies as well as a dominant lithology. The description of the dominant lithology is indicated in all cases, and descriptive information for minor lithologies is included wherever possible. Quantities of terrigenous clay were difficult to determine from smear slides and are likely to have been underestimated in some cases. Major and minor abundances from each smear slide examined aboard ship are tabulated in the smear slide summary in each site chapter.

An example of a core form with legend and explanatory notes appears in Figure 6.

\section{Sediment Color}

Colors recorded in core summaries were determined during shipboard examination immediately after the core sections were split. Experience with carbonate sediment has shown that many of the colors will fade or disappear after opening and storage. Colors particularly susceptible to rapid fading are purple, light and medium tints of blue, light bluish gray, dark greenish black, light tints of green, and pale tints of orange. These colors change with time to white or yellowish white or pale tan.

Colors were often cyclic on a scale of $20 \mathrm{~cm}$ or less. This made identification of color boundaries on the core forms virtually impossible. Large-scale color variations are shown and, where possible, small fluctuations in color are indicated.

\section{Coring Deformation}

Four degrees of deformation were recognized and are noted by symbols on the sample core form (Fig. 6). Slightly deformed cores exhibit a slight bending of bedding contacts; extreme bending defines moderate deformation. In highly deformed cores, the original bedding may be completely disrupted so as to produce a "drilling breccia." Watery intervals generally have lost all original bedding characteristics and are described as "soupy."

\section{Biostratigraphy}

The zonal schemes and radiometric ages of key datum planes used during Leg 90 are shown in Figure 7.

\section{Planktonic Foraminifers}

\section{Zones}

Five sets of zonal schemes were used in the northsouth traverse from the tropic to subantarctic waters.

$\begin{array}{ll}\text { Site } 586(=289) & \text { Tropical } \\ \text { Sites 588, 587 } & \text { Warm subtropical } \\ \text { Sites 592, 590, 591 } & \text { Cool subtropical } \\ \text { Site 593 } & \text { Temperate } \\ \text { Site 594 } & \text { Subantarctic }\end{array}$




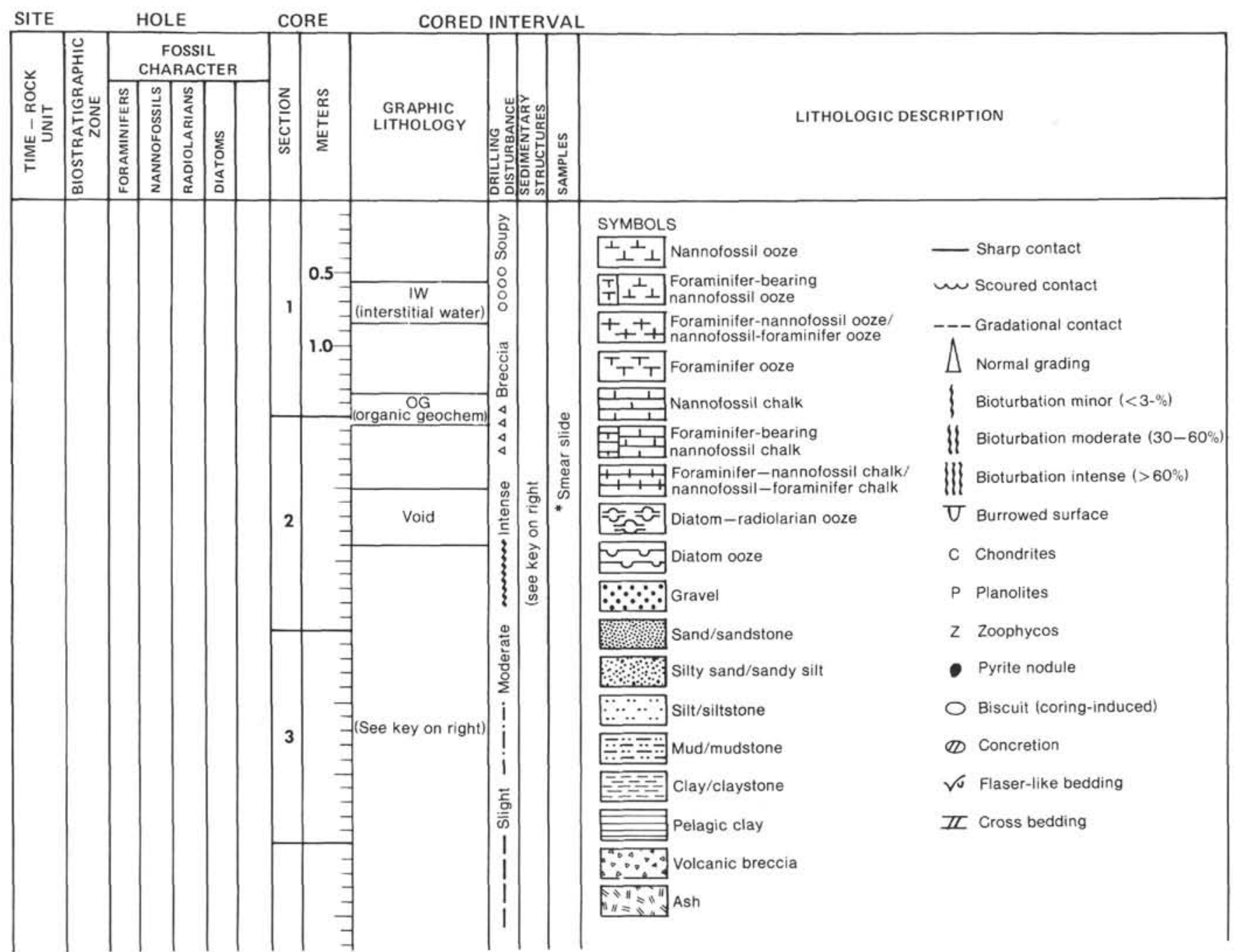

Figure 6. Sample of core form with the various symbols and descriptive codes used in this volume. Note that the graphic lithology column is based solely on smear slide estimates.

\section{Zonal Markers}

The zonal boundaries are defined on the initial appearances extinctions of zone fossils.

\section{Diachronic Nature of Some Zonal Boundaries}

1. The Globorotalia truncatulinoides Zone was recognized at Sites 586 through 592 but at Sites 593 and 594 its cryptogenic (sudden, nonevolutionary) appearance was stratigraphically later because the Globorotalia truncatulinoides ancestor $G$. tosaensis was not present.

2. Globorotalia inflata Zone. The base of the zone in the upper Pliocene, based on the first appearance of the zone fossil, appears to be reliable at Sites 592 and 593 because forms displaying its evolution from its immediate ancestor Globorotalia puncticulata are also present. There is evidence based on diatoms that the appearance of $G$. inflata at Site 594 is stratigraphically late and occurs in the Pleistocene.

3. At Sites 587 and 588 the first appearances of $G$. puncticulata and $G$. inflata are probably stratigraphically late because they evolved farther south and later migrated northward.

\section{Major Boundaries}

The planktonic foraminifer and calcareous nannoplankton species used to identify major boundaries are shown in Figure 8. There are slight offsets regarding these boundaries depending on the fossil group used. This is discussed in Martini et al. (this volume). For general uniformity foraminifer-based boundaries were used in this volume except in the individual fossil chapters.

\section{Calcareous Nannoplankton}

The standard calcareous nannoplankton zonation (Martini, 1971) is used at all sites to identify nannoplankton zones. However, from Site 592 southward, zones based on Discoaster, Ceratolithus, Catinaster, and Sphenolithus species had to be combined because most of them do not occur in subantarctic waters. In these cases the zones are identified as NN13/NN12, NN19a/NN16, etc. Zones NN11 and NN19 can be subdivided into two subzones each with additional letters $\mathrm{a}$ or $\mathrm{b}$ behind the numbers (e.g., NN11a). For further details see Martini (this volume) and Lohman (this volume). 


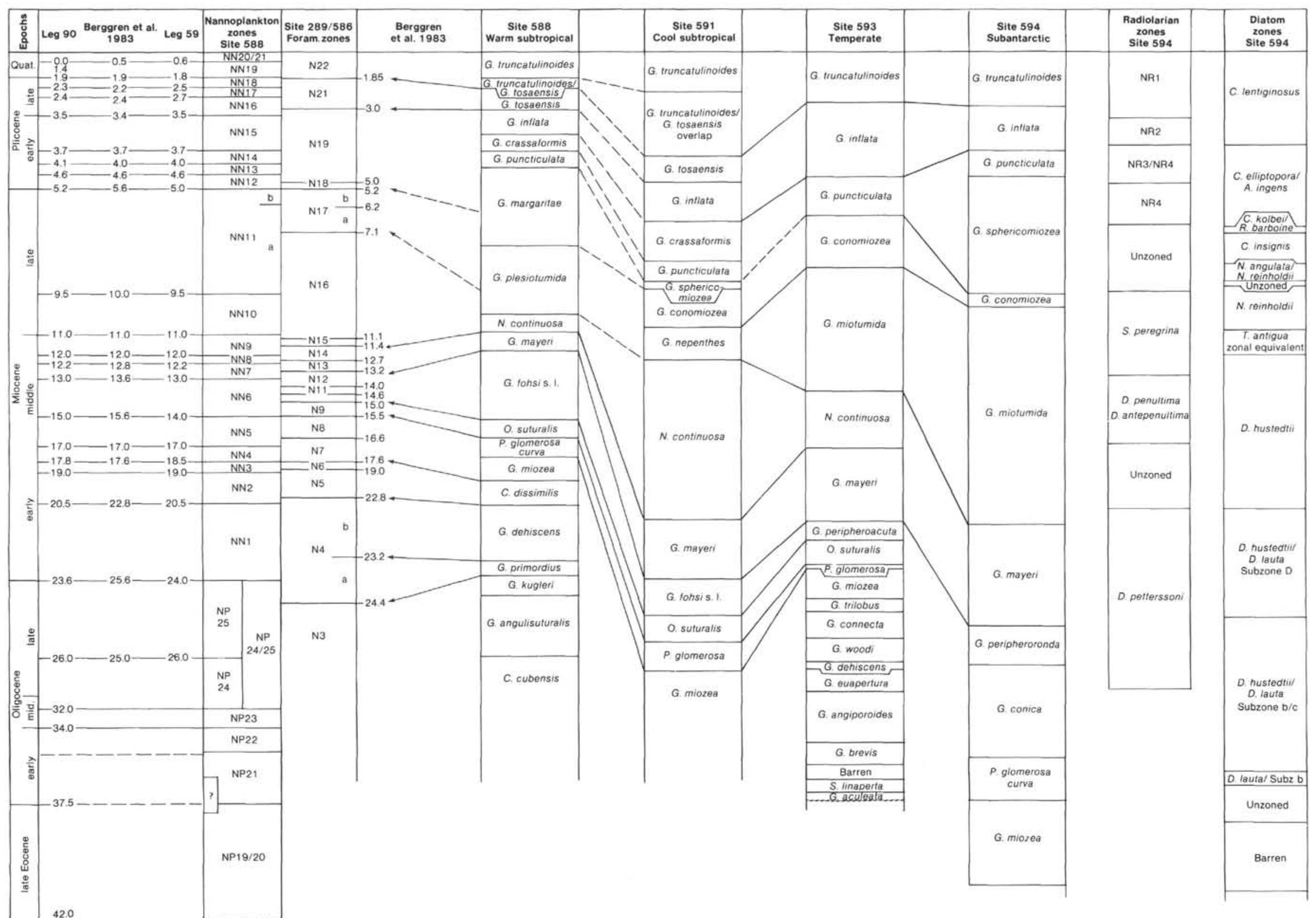

Figure 7. Leg 90 late Eocene-Quaternary planktonic zones and datums. 


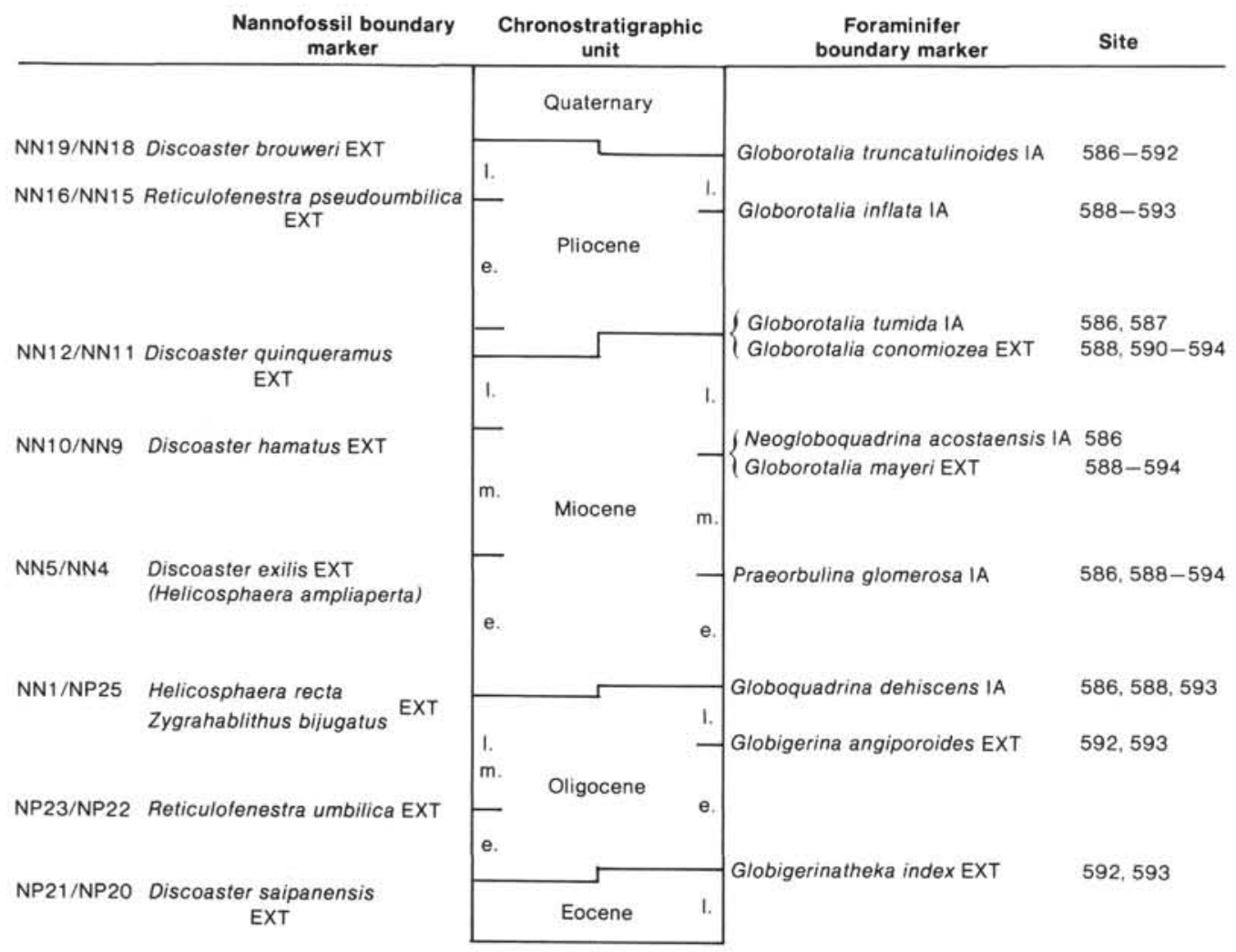

Figure 8. Nannofossils and planktonic foraminifers used to identify major boundaries. Ext $=$ extinction; IA = initial appearance.

\section{Silicoflagellates}

The high northern latitude silicoflagellate zonation used during Leg 38 (Martini and Müller, 1976) is employed for zonation in the Neogene of Sites 591 and 594 and in the Eocene of Site 588.

\section{Radiolarians and Diatoms}

Radiolarian and diatom zonations were used at Site 594. The radiolarian zonation is a mixture of tropical and subantarctic zones (Riedel and Sanfilippo, 1977; Chen, 1975; Caulet, 1982), the diatom Antarctic/subantarctic zones are after Weaver and Gombos (1981) and Ciesielski (1983), and the mid-latitude zones of Barron $(1980,1981)$.

\section{Abbreviations}

$\begin{array}{ll}\text { HPC } & \text { Hydraulic piston corer } \\ \text { VLHPC } & \text { Variable-length hydraulic piston corer } \\ \text { XCB } & \text { Extended core barrel } \\ \text { BSF } & \text { Below seafloor } \\ \text { BHA } & \text { Bottom-hole assembly } \\ \text { DPM depth } & \text { Drill pipe measured depth } \\ \text { CC } & \text { Core catcher } \\ \text { PDR } & \text { Precision depth recorder } \\ \text { OG } & \text { Organic geochemistry } \\ \text { IW } & \text { Interstitial water } \\ \text { GRAPE } & \text { Gamma ray attenuation porosity evaluator } \\ \text { IA } & \text { Initial appearance (biostratigraphic context) } \\ \text { LA } & \text { Last appearance (biostratigraphic context) }\end{array}$

The following abbreviations and units are used in the paleomagnetic reports:

$\begin{array}{ll}\text { NRM } & \text { Natural remanent magnetization } \\ \mathrm{AF} & \text { Alternating field } \\ \mathrm{MDF} & \text { Median destructive field } \\ \mu \mathrm{G} & 10^{-6} \text { gauss }\left(=1 \mathrm{~mA} \cdot \mathrm{m}^{-1}\right) \text {, unit of intensity of } \\ & \text { magnetization, i.e., magnetic moment per unit } \\ & \text { volume. } \\ \mathrm{Oe} & \begin{array}{c}\text { oersted, unit of magnetic field strength. } 10 \mathrm{Oe} \text { is } \\ \text { equivalent to a magnetic flux density of } 1 \mathrm{mT} \text { in }\end{array} \\ & \begin{array}{l}\text { a vacuum. } \\ \mathrm{mT}\end{array} \\ & 10^{-3} \text { tesla, SI unit of magnetic flux density (induc- } \\ \mu \mathrm{G} / \mathrm{Oe} & \text { tion). }\end{array}$
SI units.

The magnetic polarity time scale used is that described by Berggren et al. (in press).

\section{REFERENCES}

Barron, J. A., 1980. Lower Miocene to Quaternary diatom biostratigraphy of Leg 57, off northeastern Japan, Deep Sea Drilling Project In Scientific Party, Init. Repts. DSDP, 56, 57, Pt. 2: Washington (U.S. Govt. Printing Office), 641-686.

1981. Late Cenozoic diatom biostratigraphy and paleoceanography of the middle latitude eastern North Pacific, Deep Sea Drilling Project Leg 63. In Yeats, R. S., Haq, B. U., Init. Repts. $D S D P, 63$ : Washington (U.S. Govt. Printing Office), 507-538.

Bennett, R. H., and Keller, G. H., 1973. Physical properties evaluation. In van Andel, Tj. H., Heath, G. R., et al., Init. Repts. DSDP, 16: Washington (U.S. Govt. Printing Office), 513-521.

Berggren, W. A., Kent, D. V., and Van Couvering, J. A., in press. Neogene chronology and chronostratigraphy. Geol. Soc. London.

Boyce, R. E., 1973. Appendix I. Physical property-methods. In Edgar, N. T., Saunders, J. B., et al., Init. Repts. DSDP, 15: Washington (U.S. Govt. Printing Office), 1115-1128.

1976. Definitions and laboratory techniques of compressional sound velocity parameters and wet-water content, wet-bulk density, and porosity parameters by gravimetric and gamma-ray at- 
tenuation techniques. In Schlanger, S. O., Jackson, E. D., et al., Init. Repts. DSDP, 33: Washington (U.S. Govt. Printing Office), 931-958.

1977. Deep Sea Drilling Project procedures for shear strength measurement of clayey sediment using modified Wykeham Farrance laboratory vane apparatus. In Barker, P. F., Dalziel, I. W. D., et al., Init. Repts. DSDP, 36: Washington (U.S. Govt. Printing Office), 1059-1068.

Burns, R. E., Andrews, J. E., et al., 1973. Init. Repts. DSDP, 21: Washington (U.S. Govt. Printing Office).

Caulet, J. P., 1982. Faunes de radiolaires et fluctuations climatiques dans les sédiments de l'océan indien austral: une nouvelle biozonation. Bull. Soc. Geol. France, Ser. 7, 24:555-562.

Chen, P. -H., 1975. Antarctic radiolaria. In Hayes, D. E., Frakes, L. A., et al., Init. Repts. DSDP, 28: Washington (U.S. Govt. Printing Office), 437-513.

Ciesielski, P. F., 1983. The Neogene and Quaternary diatom biostratigraphy of subantarctic sediments, Deep Sea Drilling Project Leg 71. In Ludwig, W. J., Krasheninnikov, V. A., Init. Repts. DSDP, 71, Pt. 2: Washington (U.S. Govt. Printing Office), 635-665.

Evans, H. B., 1965. GRAPE-A device for continuous determination of material density and porosity. Trans. SPWIA Logging Symposium, 6th Ann. Dallas, Tx., 2:B-1-B25.

Jongsma, D., and Mutter, J. C., 1978. Nonaxial breaching of a rift valley: Evidence from the Lord Howe Rise and the southeastern Australian Margin, Earth Planet. Sci. Lett., 39:226-234.

Karlin, R., and Levi, S., 1983. Diagenesis of magnetic minerals in Recent hemipelagic sediments. Nature, 303:327-330.

Kennett, J. P., Burns, R. E., Andrews, J. E., Churkin, M., Davies, T. A., et al., 1972. Australia-Antarctic continental drift, paleocirculation changes and Oligocene deep-sea erosion. Nature Phys. Sci., 239(91):51-55.

Knox, G. A., 1970. Biological oceanography of the South Pacific. In Wooster, W. S. (Ed.), Scientific Exploration of the South Pacific: Washington (National Academy of Science), pp. 155-182.

McDougall, I., and van der Lingen, G. J., 1974. Age of rhyolites of the Lord Howe Rise and the evolution of the southwest Pacific Ocean. Earth Planet. Sci. Lett., 21:117-126.
Mammerickx, J., Chase, T. E., Smith, S. M., and Taylor, I. L., 1971. Bathymetry of the South Pacific: La Jolla (Scripps Institution of Oceanography).

Martini, E., 1971. Standard Tertiary and Quaternary calcareous nannoplankton zonation. Proc. II Planktonic Conf., Roma 1970 (Vol. 2): Rome (Edizioni Tecnoscienza), 739-785

Martini, E., and Müller, C., 1976. Eocene to Pleistocene silicoflagellates from the Norwegian-Greenland Sea (DSDP Leg 38). In Talwani, M., Udintsev, G., et al., Init. Repts. DSDP, 38: Washington (U.S. Govt. Printing Office), 857-895.

Mayer, L. A., 1982. Physical properties of sediment recovered on Deep Sea Drilling Project Leg 68 with the hydraulic piston corer. In Prell, W. L., Gardner, J. V., et al., Init. Repts. DSDP, 68: Washington (U.S. Govt. Printing Office), 365-382.

Morin, R., and Silva, A. J., 1984. Effects of high pressure-high temperature on some physical properties of ocean sediments. J. Geophys. Res., 89:511-526.

Müller, G., and Gastner, M., 1971. The "Karbonat Bombe," a simple device for the determination of carbonate content in sediments, soils, and other materials. N. Jahrb. Mineral. Monatsh., 10: 466-469.

Riedel, W. R., and Sanfilippo, A., 1977. Cenozoic Radiolaria. In Ramsay, A. T. S. (Ed.), Oceanic Micropaleontology: New York (Academic Press), pp. 847-912.

Von Herzen, R. P., and Maxwell, A. E., 1959. The measurement of thermal conductivity of deep-sea sediments by a needle-probe method. J. Geophys. Res., 64:1557-1563.

Weaver, F. M., and Gombos, A. M., 1981. Southern high latitude diatom biostratigraphy. In Warme, T. E., Douglas, R. C., and Winterer, E. L. (Eds.), The Deep Sea Drilling Project: A Decade of Progress. Soc. Econ. Paleont. Mineral. Spec. Publ., 32:445-470.

Wilcox, J. B., Symonds, P. A., Hinz, K., and Bennett, D., 1980. Lord Howe Rise, Tasman Sea-preliminary geophysical results and petroleum prospects. B.M.R. J. Aust. Geol. Geophys., 5:225-236.

Date of Acceptance: 12 December 1983 